\title{
Koichiro NAgaURA: Genetical Study on the Olfactory Response of Silk-worm
}

\section{虫児の嗅覚に関する遺伝学的研究}

\author{
福島県立医科大学衛生学教室（主任 星島啓一郎教授）
}

長浦 小- 郎

\section{I. 緒言}

Beidler 1) は嗅覚の生理学的な究明は, 古く から多くの研究がなされているが，その構造 と機能の関係は未だに不明確な点が多い.嗅覚 により生活体が 10-13 モル程度の浱度域に抏 いても，その物質を認知し得ること，またさ らにつけ加えれば，分子構造のよく類似した 物質をる互いに識別する能力は，驚くべきで あると云つている。

彼はさらに語を次いで，生化学及び生物々 理学等の境界領域からの, 嗅覚研究への新ら しい方法論の示唆があらわれた現在, 生理学 者は他の領域の学者と協同のもとに，嗅覚の 研究をより精力的に進めるべきであると提唱 している。

な持心理学者の立場から Wenzel 2) 物理学 者の立場から Greenspan ${ }^{3}$ ) 化学者の立場から Sumner 4) がこれに対し賛意を表している.

我々の教室では味覚及び嗅覚に関する研究 をしているこー14).

我が教室の横山は7) 八ツカネズミの系統に よつて味覚の感受性の相違あることを確め, さらにそれが皮毛の黒白とどのような関係に あるかを知るために，ハッカネズミの黒白計 6 系統について，各味覚の閾值を測定した結 果, 白色系が味覚に対する感受性が高いこと を認め，さらに副腎，甲状腺及び肝機能の低 下は，いづれる味覚閾値を高める傾向にある ことを確めた。

また池田 ${ }^{10)}$ 11) は人について嗅覚の研究を
進めているが，著者は以下述べる4 項目の理 由により，実験動物として家亘を取り上げ嗅 覚6)の研究を企図した。

すなわち，1）家亘は遗伝的によく研究され て扮り，一世代の長さが短く一年間に七世代 を観察することができること，2）1頭の母蛾 の産卵数の多少は亘種によつて差があるが，

概敉 1 蛾平均 500 800 個と云われているた め，同一品種の集団として極めてとり报い易 く，また観察が便利であること，3）方化始め てからの虫児の日令の揃い易いものが得られ ること，4）本論文ではとり上げなかつたが， 家亘の生化学, 特に遗伝生化学的な研究が吉 川ら15）を始めとする多くの研究者により極め て詳細になされているため, 将来の生化学的 研究の材料としては，䓕だ好適であること 等々である。

著者 ${ }^{5)}$ はさきに家虫を用いて味覚の研究を 報告したが，田中15）小野16）17）らによると， 虫児が桑葉の優劣を知る場合には，味覚，触 覚, 視覚等によるよりも, 嗅覚力による場合 が大であること，及び蛋児の各令期の中で， ふ化当時の蟻虫が特に嗅覚が鋭敏と云われて いること等により，実験材料としてこれら蟻 龺を利用した。

な持盆化性の実験をなすには，品種によつ て異つていると思われる, 蟻昋の匍匐速度に ついての基礎的データが, 当然必要となつて くるのでそれを測定し，次いで各系亘児の嗅 覚の相違を明確にした。 
さらに桑葉以外の自然植物葉に対して 如何 なる反応を示すかを知るために，きく，やい で，权き，そらまめ，いちら゙くの5 種類をと り上げて，同様の実験を試久た。

またこれら各系蛋の遺伝的素因を追求せん として，各系の交雑種を飼育して同様の実験 を，桑葉及びその他の植物葉について実施し た。さらに蚻児の化学物質に対する䞮化性を 調べるため，脂肪酸，エステル，アルデヒド， ケトン及びアルデヒド系香料の各種 25 種の合 成試薬を使用して，これら嗅刺戟物質に対す る虫児の趨化性に関する检討を行つた。

\section{II. 実験材料及び方法}

A. 実験材料

\section{1. 蚕種}

農林省毛系試験場東北支場から分与された， 小石丸, 支 122 , 済南, 朝鮮の 4 種並びに遗 伝的因子検索の目的を以つて，これら4種か らなる 12 の交雑種を用い，いづれるら化当時 の蟻亘を実験に供した。

な扮各系虫の 形質保存状沉について述べる と，小石丸種は日本在来種の中で，むつとも 代表的なものとして 飼育されてきたもので西 る. 済南については昭和 14 年，支那より輸入 された品種で出り，農林省虫系試験場生理部 の梅谷与七郎博士により，飼育されてきたる ので出る。その後東北支場が譲渡を受けて 飼育してきたものである。また支 122 種は， \{(支 13×支 15) ×支 110\}N76 の交雑により飼 育されてきたものである。従つて殆んど他系 統（欧州または日本種）の形質は入つていな いと見なしてよいものである。最後に朝鮮種 については，これも朝鮮在来種では岕るか゚輸 入年は不明であつた。

上述の如く，これらは長年月の固定を経た 品種であり，から由来も異つているので，形 質的には全く異つたものである。

2. 植物 葉

桑葉，きく，そらまめ，ねぎ，やつで，い
ちざくの 6 種で，いゔれも採取直後の新鮮な ものを使用に供した。

3. 合成試薬

脂肪酸，エステル，ヶトソ，アルデヒド類 (和光純薬製) 及び，Dr. M. Guillotより供与 されたフランス, Roure-Bertrand Fils et Justin Du Pont 社製のアルデヒド系の香料原液を用 い，それぞれ $10 \%$ より $0.1 \%$ まで階段稀积し て使用に供した。

\section{B. 赛歌方法}

1. 測 定 法

実戨をなすには室内及び 容器内の 無気流を 条件とするので，実験室は密閉した。また亘 児は光に対して山る程度の趨化性を有すると されているので 18）19）室内は薄暗くして明る さの均等を計り, かつ実験時の室温は蛋児の 運動の適温で山る， $25^{\circ} \mathrm{C}$, 湿度 $70 \%$ 前後とし た。

容器は直径 $18 \mathrm{~cm}$ の蓋つきシャーレを用い， 蓋を透して奣児の運動を観察しうる装置とし た。シャーレの底には第 1 図の如く，墨を用

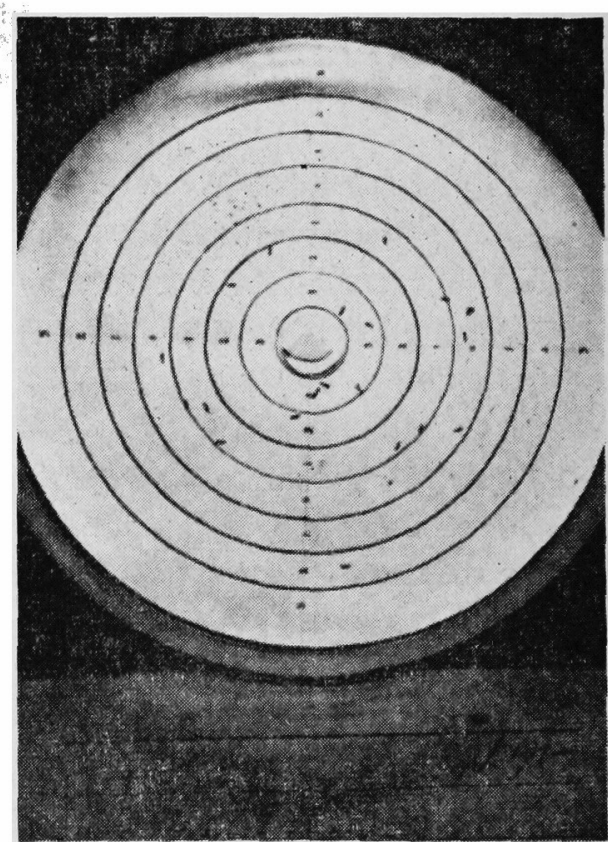

第 1 図 測 定 例 
いて $1 \mathrm{~cm}$ 毎に区画 した同心円を画き， さらにこれを直角に 4 等分した直線を引 いた。

次いで䖯児の置く 位置を決定するにあ たつては，桑葉に対 する奄児の感応距離 を前もつて知る必要 があるが，小野16）17)

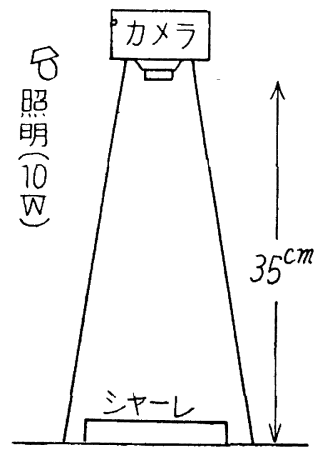

第 2 図実験装㨁 佐々木 21） らの報告及び著者の予供実験によ れば，亘児が桑葉から $4 \mathrm{~cm}$ 以上距ると，急 に趨化性の减退する事実が認められた。従つ て嗅物質を置く中心から，半径 $4 \mathrm{~cm}$ の距離 に20 頭の蟻龺を配列した。常に運動を続ける これら儀蚕を傷つけないように，にわとりの 羽根を用いて，円内を 4 等分した直線圈内に， 要児の方向の如何に係わらず自然のま〉に， それぞれ 5 頭山て計 20 頭の蟻蚕を配列した。 次いでその中心に 植物葉の場合は 細かくきさ んで $0.2 \mathrm{~g}$ を置き, 試薬については直径 $1 \mathrm{~cm}$ のろ紙（東洋万紙 No. 1) に浸ませて置いた。 しかる後に第 2 図の如き撮影装置により，

Stop-watch を用いて 2 分毎に 10 回，すなわ ち 20 分間の蟻虫の行動暦をカメラに収めた。 な打撮影時にはごく短時間に $10 \mathrm{~W} 1$ 㑬の照 明を用いた。

実験終了後，フイルムを拡大投影し黑点と して現われた蟻蛋の数，及びその移動距離を 測定した。また実験 1 回（20 分）終了矫に， 新らしい蟻曐ととりかえて，同じ方法によつ てそれぞれの植物，及び合成試薬に対して， 各系亘及び交雑種について同一方法により， それぞれ3 回延べ30回あての测定を実施した (第 1 図).

\section{2. 計 算 法}

計算に山たつては次に 述べる2つの仮定の もとに行つた。
すなわち，1）蟻虫が中央の物質に到達した 後は，それ以前の平均速度と同じ速度で甫匐 するものとしたこと．2）20 分間の実験中で は嗅物質の拡散，またもし有りとすれば嗅物 質の蟻亘体内への侵入により，その生理的条 件の変化等々, 当然経過時間に従い条件の相 違を考虑さるべきであるが，今回は 2 分毎の 測定数值を，すべて独立のものとして扱つた。

実験方法のところで述べた如く，20頭につ き計 10 回の測定，さらにそれを 3 回くり返し たので，延べ 30 回計 600 頭につき匍匐速度を 算定した。な招桑葉以外の物質による測定に ついては，桑葉に対する平均匍匐速度の比を もつて，その亘種の当該物質に対する趨化性 とした。

\section{III. 実験 結 果}

A. 純系亘種使用による実験結果

1. 桑葉に対する匍氱速度について

桑葉に対する匍匐速度を各系別に見ると第 1 表のと打りである。これによると小石丸種 が毎分 $0.70 \mathrm{~cm}$ で他の虫種に比して，かなり 高い值を示している. 次いで支 122 種の 0.24 $\mathrm{cm}$ であり，済南種の $0.16 \mathrm{~cm}$ と朝鮮種の $0.19 \mathrm{~cm}$ はほ心゙似た值を示して抒り，これらは 他查種に比較して匍氱速度は，最も低くなつ ており，各寔種間に相違が認められた。

な拈この記述に扮いて，简匐速度と云う言 藮を使つたが，当然これは昦児の盏匐速度と 桑葉に対する超化性の 2 つを含んで括り，そ の両者を鑑別ずる方法がなかつたつめ，おえ てこの表現を用いた。

2. 自然葉に対する䟉化性

さらに上述の 桑背に刘する 敷匐速度をもと 〉して, 各種の㥀物に対する趆化性を比較し た結果は第 2 表のと招りである。

これによるとそれぞれの植物に対する趨化 性については，朝解種のきくに対するるのを 除いては，桑葉に比して低い数值を示してい る。殊に㸚ぎに対してはその傾向が著明に表 
第 1 表 1 頭 1 分当り桑桬に対する氭匍速度 $(\mathrm{cm})$

\begin{tabular}{|c|c|c|c|c|c|c|c|c|c|c|c|c|}
\hline \multirow[b]{2}{*}{ 時: 閶] } & \multicolumn{2}{|c|}{ 小 石 } & 丸 & \multicolumn{3}{|c|}{122} & \multicolumn{2}{|l|}{ 済 } & 南 & \multicolumn{2}{|l|}{ 钥 } & 群 \\
\hline & 1 & 2 & 3 & 1 & 2 & 3 & 1 & 2 & 3 & 1 & 2 & 3 \\
\hline 2 分 時: & 0.755 & 0.700 & 0.725 & 0.135 & 0.450 & 0.225 & 0.250 & 0.225 & $0.200^{\prime}$ & 0.101 & 0.025 & 0.325 \\
\hline 4 & 0.738 & 0.575 & 0.700 & 0.085 & 0.325 & 0.325 & 0.192 & 0.187 & 0.175 & 0.162 & 0.075 & 0.313 \\
\hline 6 & 0.750 & 0.583 & 0.692 & 0.068 & 0.292 & 0.292 & 0.123 & 0.183 & 0.158 & 0.108 & 0.075 & 0.333 \\
\hline 8 & 0.752 & 0.573 & 0.679 & 0.035 & 0.310 & 0.311 & 0.115 & 0.162 & 0.150 & 0.119 & 0.084 & 0.333 \\
\hline 10 & 0.748 & 0.582 & 0.694 & 0.040 & 0.332 & 0.327 & 0.110 & 0.153 & 0.160 & 0.145 & 0.085 & 0.340 \\
\hline 12 & 0.733 & 0.638 & 0.728 & 0.035 & 0.340 & 0.340 & 0.106 & 0.179 & 0.150 & 0.157 & 0.093 & 0.341 \\
\hline 14 & 0.756 & 0.643 & 0.717 & 0.039 & 0.340 & 0.329 & 0.100 & 0.187 & 0.160 & 0.140 & 0.093 & 0.360 \\
\hline 16 & 0.759 & 0.644 & 0.722 & 0.063 & 0.342 & 0.348 & 0.093 & 0.181 & 0.156 & 0.150 & 0.097 & 0.354 \\
\hline 18 & 0.780 & 0.657 & 0.726 & 0.038 & 0.334 & 0.335 & 0.092 & 0.177 & 0.169 & 0.177 & 0.095 & 0.361 \\
\hline 20 & 0.783 & 0.672 & 0.783 & 0.038 & 0.344 & 0.331 & 0.092 & 0.170 & 0.187 & 0.166 & 0.100 & 0.362 \\
\hline 平均值 & \multicolumn{3}{|c|}{$0.70 \pm 0.15$} & \multicolumn{3}{|c|}{$0.24 \pm 0.09$} & \multicolumn{3}{|c|}{$0.16 \pm 0.07$} & \multicolumn{3}{|c|}{$0.19 \pm 0.07$} \\
\hline
\end{tabular}

第 2 表 自然薬に対する趨化性

\begin{tabular}{|c|c|c|c|c|c|c|}
\hline 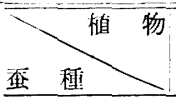 & 葉 & そらまめ & $p \supset \tau$ & 权 & いちら゙く & き \\
\hline 小 石 丸 & $\begin{array}{l}1.00 \\
(0.70 \mathrm{~cm})\end{array}$ & $\begin{array}{l}0.19 \\
(0.13 \mathrm{~cm})\end{array}$ & $\begin{array}{l}0.54 \\
(0.38 \mathrm{~cm})\end{array}$ & $\begin{array}{l}0.07 \\
(0.05 \mathrm{~cm})\end{array}$ & $\begin{array}{c}0.38 \\
(0.25 \mathrm{~cm})\end{array}$ & $\begin{array}{c}0.32 \\
(0.21 \mathrm{~cm})\end{array}$ \\
\hline 122 & $\begin{array}{c}1.00 \\
(0.24)\end{array}$ & $\begin{array}{c}0.21 \\
(0.05)\end{array}$ & $\begin{array}{c}0.17 \\
(0.04)\end{array}$ & $\begin{array}{c}0.08 \\
(0.02)\end{array}$ & $\begin{array}{c}0.09 \\
(0.02)\end{array}$ & $\begin{array}{c}0.36 \\
(0.08)\end{array}$ \\
\hline 済 & $\begin{array}{c}1.00 \\
(0.16)\end{array}$ & $\begin{array}{c}0.12 \\
(0.02)\end{array}$ & $\begin{array}{c}0.12 \\
(0.02)\end{array}$ & $\begin{array}{c}-0.01 \\
(-0.002)\end{array}$ & $\begin{array}{c}0.03 \\
(0.00: 1)\end{array}$ & $\begin{array}{c}0.29 \\
(0.05)\end{array}$ \\
\hline 湤 & $\begin{array}{c}1.00 \\
(0.19)\end{array}$ & $\begin{array}{c}0.16 \\
(0.03)\end{array}$ & $\begin{array}{c}0.16 \\
(0.03)\end{array}$ & $\begin{array}{c}0.21 \\
(0.04)\end{array}$ & $\begin{array}{c}0.21 \\
(0.04)\end{array}$ & $\begin{array}{c}1.37 \\
(0.22)\end{array}$ \\
\hline
\end{tabular}

（）内は 1 頭 1 分当り㓩甸速度を示す

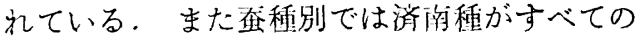
植物に対して数値が低く，中でも㸚ぎの場合 は（一）を示して招り，こ礼は後退を意味つ けるものである。

な招小石丸種については，やつで及びいち よ゙くに対する䞲化性は，桑菜に対するそれよ りは扮とつているが，他曐種に比してかなり 高い趨化性を示している。

3. 合成試泳に対する越化性

合成試薬に 対する実験結果は第 3 表の如く
である。すなわち小石丸種を除いては，他系 亘種はすべての試薬に対して，竖度 $0.1 \%$ か ら $10 \%$ までの範囲では䞶化性は認められなか つた。また小石丸種に拈いても，ェステル， ケトン，脂肪酸系統に対しては他蚕種と同様 に鯬性を認めることはできなかつた。

しかし，アルデヒド系統にのみその濃度 10 \%に上げた場合，始めてかなり高い趨化性を みることができた。

そこで小石丸種による上記アルデヒド系試 
第 3 表 合成試薬に対する䞶化性

\begin{tabular}{|c|c|c|c|c|c|c|c|}
\hline 群 & & 試 & 濃度 $(\%)$ & 小石丸 & 支 122 & 済 南 & 朝 鮮 \\
\hline エステル & & $\begin{array}{l}\text { Ethyl-formate } \\
\text { Ethyl-butyrate } \\
\text { Ethyl-palmitate }\end{array}$ & $\begin{array}{l}0.1 \sim 10 \\
0.1 \sim 10 \\
0.1 \sim 10\end{array}$ & $(-)$ & $(-)$ & $(-)$ & $(-)$ \\
\hline 脂 眆 酸 & & $\begin{array}{l}\text { Acetic acid } \\
\text { Propionic acid } \\
\text { n-Butylic acid }\end{array}$ & $\begin{array}{l}0.1 \sim 10 \\
0.1 \sim 10 \\
0.1 \sim 10\end{array}$ & $(-)$ & $(-)$ & $(-)$ & $(-)$ \\
\hline アルデヒト & & $\begin{array}{l}\text { Form-aldehyde } \\
\text { Aceto-aldehyde } \\
\text { Propion-aldehyde } \\
\text { n-Butyr-aldehyde } \\
\text { Iso-valerian-aldehyde } \\
\text { n-capron-aldehyde } \\
\text { Enanthol-aldehyde } \\
\text { Capryl-aldehyde } \\
\text { Pelargon-aldehyde } \\
\text { Caprin-aldehyde } \\
\text { Benz-aldehyde }\end{array}$ & \begin{tabular}{c|}
10 \\
10 \\
10 \\
10 \\
10 \\
$0.1 \sim 10$ \\
$0.1 \sim 10$ \\
$0.1 \sim 10$ \\
10 \\
$0.1 \sim 10$ \\
10
\end{tabular} & $\begin{array}{l}(+) \\
(+) \\
(+) \\
(t) \\
(t) \\
(-) \\
(-) \\
(-) \\
(+) \\
(-) \\
(+)\end{array}$ & $(-)$ & $(-)$ & $(-)$ \\
\hline ケ ト & & $\begin{array}{l}\text { Aceton } \\
\text { Methamine }\end{array}$ & $\begin{array}{l}0.1 \sim 10 \\
0.1 \sim 10\end{array}$ & $\begin{array}{l}(-) \\
(-)\end{array}$ & $(-)$ & $(-)$ & $(-)$ \\
\hline 香 & 㘰 & $\begin{array}{l}\text { Vanillin } \\
\text { Aldehyde } \mathrm{C}_{10} \\
\boldsymbol{\alpha} \text {-Amyl cinnamic aldehyde } \\
\text { Hydoxy citronell aldehyde } \\
\text { Anis-aldehyde }\end{array}$ & $\begin{array}{c}10 \\
10 \\
10 \\
0.1 \sim 10 \\
0.1 \sim 10\end{array}$ & $\begin{array}{l}(+) \\
(+) \\
(+) \\
(-) \\
(-)\end{array}$ & $(-)$ & $(-)$ & $(-)$ \\
\hline
\end{tabular}

薬及び香料に対する趨化性の差異を比較した 結果は第 4 表のと挔りである。これによると 前述の自然葉に対する場合と同様に，すべて の試薬に対しても，その趨化性は桑葉に比べ てはるかに低い值を示している。

すなわち，本実験の中でもつとも高い趨化 性を示す Form-aldehyde に和いても嚾かに 0.31 であり, 次いで香料の Vanillin が 0.28 , Aldehyde $\mathrm{C}_{10}$ の $0.27, \alpha$-Amyl-cinnamicaldehyde の0.26となつている，最も低いの が Benz-aldehyde の0.12であり, Propionaldehyde Pelargon-aldehyde のそれぞれ 0.14 がこれに次いでいる。な招この場合は, 試薬 の炭素数ないしはその化学構造との 特別な関
第4 表 アルデヒド及び香料に対 する小石丸種の趨化性

\begin{tabular}{|c|c|c|}
\hline & 試 & 趄 化 性 \\
\hline アルデヒド & $\begin{array}{l}\text { Form-aldehyde } \\
\text { Acet-aldehyde } \\
\text { Propion-aldehyde } \\
\text { n-Butyr-aldehyde } \\
\text { Iso-valerian-aldehyde } \\
\text { Pelargon-aldehyde } \\
\text { Benz-aldehyde }\end{array}$ & $\begin{array}{l}0.31(0.22 \mathrm{~cm}) \\
0.21(0.15) \\
0.14(0.10) \\
0.22(0.16) \\
0.22(0.16) \\
0.14(0.10) \\
0.12(0.09)\end{array}$ \\
\hline 香 & $\begin{array}{l}\text { Vanillin } \\
\text { Aldehyde } \mathrm{C}_{10} \\
\alpha \text {-Amyl cinnamic- } \\
\quad \text { aldehyde }\end{array}$ & $\begin{array}{l}0.28(0.20) \\
0.27(0.19) \\
0.26(0.18)\end{array}$ \\
\hline
\end{tabular}


倸は認められなかつた。

B. 交雑種使用による遺伝学的実験

1. 桑葉に対する䈻匐速度

亘児の各品種間に扮ける差異を遺伝学的に 究明するため，桑葉に対する匍匐速度につい て，それぞれの交雑種と各々の両親との比を 検討した結果は，第 5 表に示すと招りである。

第 5 表 交雑種の桑葉に対する匍舅速度

\begin{tabular}{|c|c|c|c|c|c|}
\hline \multirow{2}{*}{\multicolumn{2}{|c|}{$\frac{\text { 交 }}{9}$}} & 雑 & \multicolumn{2}{|c|}{ 原 皤対比 } & \multirow{2}{*}{ 匍匐距離 } \\
\hline & & $\delta$ & 우 & $\delta$ & \\
\hline 小 & 石 丸 & 済南 & 0.59 & 2.56 & $0.14 \mathrm{~cm}$ \\
\hline 小 & 石 丸 & 朝 & 0.87 & 3.21 & 0.61 \\
\hline 小 & 石 丸 & 支 $\quad 122$ & 0.87 & 2.54 & 0.61 \\
\hline 済 & 南 & 小石 丸 & 1.50 & 0.34 & 0.24 \\
\hline 済 & 南 & 支 $\quad 122$ & 1.12 & 0.75 & 0.18 \\
\hline 支 & 122 & 小石 丸 & 0.95 & 0.33 & 0.23 \\
\hline 朝 & 鮮 & 小石 丸 & 0.90 & 0.24 & 0.17 \\
\hline 朝 & 鮮 & 122 & 0.78 & 0.62 & 0.15 \\
\hline 支 & 122 & 朝 & 2.05 & 2.58 & 0.45 \\
\hline 支 & 122 & 珮 & 1.08 & 1.62 & 0.26 \\
\hline 済 & 南 & 朝 & 2.31 & 1.95 & 0.37 \\
\hline 朝 & 鮮 & 済 & 3.52 & 4.19 & 0.67 \\
\hline \multirow{4}{*}{\multicolumn{2}{|c|}{ 参考 }} & \multicolumn{3}{|c|}{$0.70 \mathrm{~cm}$} & \\
\hline & & 支 122 & \multicolumn{2}{|c|}{0.24} & \\
\hline & & 済 献 & \multicolumn{2}{|c|}{0.16} & \\
\hline & & 胡 蟹 & & & \\
\hline
\end{tabular}

すなわち，小石丸種を古僋にした場合の原 種小石丸種に対する比は，いつれれも低い値を 示して招り，同じく支 122 種については， 支 $122 \times$ 小石丸種の 0.95 と注づ原種に近いも のを除いては，いづれも原種に比べて大きな 値を示している，问様に済南種の場合に招い てはすべての値は原種よりもその比は大であ つた。

さらに朝鮮種については，古朝鮮 $\times$ 済南種 の 3.52 が他に比して最も高い数値をみせてい るが，他は原種よりも低い値を示している。

一方側からみた場合は次の如くであつた。 すなわち, 済南種, 朝焦種, 支 122 種の 3

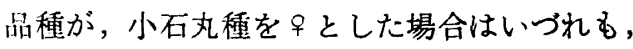
原種に比べて2〜3 倍の高い值を示している。

同じように支 122 をなとした昜合のそれら は，支 $122 \times$ 小石丸種の 0.95 を除いては， 原種よりも高い値を示している。 また済南種 を早とした場合に招いては，〕済南メ朝鮮種 の 1.95 のみが原種より高く, 他の 2 品種は低 くなつている。さらに朝鮮種をすとした場合 には, 守朝鮮 $\times$ 済南種の 4,19 という極めて高 い値を示するのも㟧るが，他はいづれも低く なつている。

以上の諸点から

1）交雑によつて現われた速度が，原種のい づれか一方の值より大となり，またわ小とな つたもの.

2）交雑によつていづれの原種よりもその比 が小となつたもの.

3）交雑によつていづれも原種に比して大な る值を示したもの.

以上の 3 群に別けることができる．すなわ ち,

1）原種小石丸種をとした場合の。側 3 品 種の，原種に対する比はいづれも高い値を示 していること，また済南種に挌いては逆に。 侧の 2 品種 (小石丸, 支 122) 原種には比して 低くなつている，つまり小石丸種以外の 3 品 種は古小石丸種の因子によつて，その溨匐速 度は大となり，また佩南種の因子によつて 小石丸種及び支 122 種は小となることである.

すなわち，この場合は一見 側の因子が強 く作用しているよ5に思われる。

2) 支 122 種及び朝鮮種を京とした小石丸種 の場合は，京占いづれの侧についてもその値 は原種に比して小となる。

3）支 122 種をけとした朝鮮種及び済南種, 済南種を゚とした朝鮮種，朝鮮種を゚とした 済南種の場合は杂合いづれに括いても，その 值は原種に比して大となつている.

2, 交雑種の自然葉に対する超化性 交雑種の自然葉に対する超化性を，きく及 
びいちら゙くについて示せば第 6 表の通りで， 原種に扣いては趨化性が 極めて低かつたのに

第 6 表 交雑種の自然葉に対する盘化性

\begin{tabular}{|c|c|c|c|c|c|c|}
\hline & 交 & 杂 & & 種 & \multirow{2}{*}{ き } & \multirow{2}{*}{ いちぶく } \\
\hline & $q$ & & \multicolumn{2}{|r|}{$\hat{\delta}$} & & \\
\hline 小 & 石 & 丸 & 済 & 南 & 1.03 & 0.46 \\
\hline 小 & 石 & 丸 & 朝 & 鮮 & 1.00 & 1.18 \\
\hline 小 & 石 & 丸 & 支 & 122 & 1.25 & 0.90 \\
\hline 支 & & 122 & 小 & 石 丸 & 1.87 & 1.37 \\
\hline 支 & & 122 & 朝 & 鮮 & 1.32 & 1.27 \\
\hline 支 & & 122 & 済 & 南 & 1.12 & 1.04 \\
\hline 済 & & 南 & 小 & 石 丸 & 0.55 & 0.33 \\
\hline 済 & & 南 & 支 & 122 & 0.15 & 0.18 \\
\hline 済 & & 南 & 朝 & 鮮 & 1.98 & 1.48 \\
\hline 朝 & & 鮮 & 小 & 石 丸 & 0.73 & 0.52 \\
\hline 朝 & & 鮮 & 支 & 122 & 0.88 & -0.03 \\
\hline 朝 & & 鮮 & 済 & 南 & 1.49 & 1.28 \\
\hline
\end{tabular}

第 7 表 交雑種の自然葉に対する趨化性 の原種のそれに対する比

(1) く

\begin{tabular}{|c|c|c|c|c|c|c|c|c|}
\hline & 交 & & & 種 & & 原 種 & 対 & 比 \\
\hline & 우 & & & $\delta$ & & 우 & & $\delta$ \\
\hline 朝 & & 鮮 & 小 & 石 & 丸 & 0.53 & & 2.28 \\
\hline 朝 & & 鮮 & 支 & & 122 & 0.64 & & 2.44 \\
\hline 朝 & & 鮮 & 済 & & 南 & 1.07 & & 5.14 \\
\hline 小 & 石 & 丸 & 朝 & & 鮮 & 3.12 & & 0.73 \\
\hline 支 & & 122 & 朝 & & 鮮 & 3.66 & & 0.96 \\
\hline 済 & & 南 & 朝 & & 鮮 & 6.81 & & 1.44 \\
\hline 済 & & 南 & 支 & & 122 & 0.51 & & 0.41 \\
\hline 小 & 石 & 丸 & 済 & & 南 & 3.29 & & 3.55 \\
\hline 小 & 石 & 丸 & 支 & & 122 & 3.90 & & 3.47 \\
\hline 支 & & 122 & 小 & 石 & 丸 & 5.19 & & 5.84 \\
\hline 支 & & 122 & 済 & & 南 & 3.11 & & 3.51 \\
\hline 済 & & 南 & 小 & 石 & 丸 & 1.90 & & 1.72 \\
\hline
\end{tabular}

参考 小石丸 0.32

支 1220.36

済南 0.29

朝 鮮 1.37
比べ，むしろ桑染に対する以上の，或は殆ん ど等しい艋化性を示したものが多かつたのが 目立つた。

次いで原種のきくへの遛化性に対する交雑 種のそれを比で示すと第 7 表の通りである.

1）さきに純系亘のきくに対する遛化性の実 験で示した如く，朝鮮種は 1,37 と特巽的に， きくに対し強い趨化性を示したが，今回の交 雑種に打いては次の如き結果を示した。

すなわち，朝鮮種を原種とした場合は，趨 化性は朝鮮種に比べてや〉扣ちる場合もあつ

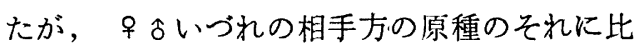
して非常な上界が認められた。

2) 特徴的なのは, ○済南種 $\times$ 支 122 種の場 合であつて，方いづれの原種に比してる小 となつている．その他の交雑種はいづれる。 ふいづれの原種に比べてもその趨化性は大と なつている.

さらに原種のいちら゙くへの䞶化性に 対する

第 8 表 交雑種の自然葉に対する趨化性 の原種のそれに対する比

(2) いちな゙く

\begin{tabular}{|c|c|c|c|c|c|c|c|c|}
\hline & 交 & & & 種 & & 原 種 & 対 & 比 \\
\hline & 우 & & & $\hat{\delta}$ & & 우 & & $\delta$ \\
\hline 済 & & 南 & 小 & 石 & 丸 & 11.00 & & 0.87 \\
\hline 済 & & 南 & 支 & & 122 & 6.00 & & 2.00 \\
\hline 済 & & 南 & 朝 & & 鮮 & 49.33 & & 7.05 \\
\hline 小 & 石 & 丸 & 済 & & 南 & 1.21 & & 15.33 \\
\hline 支 & & 122 & 済 & & 南 & 11.55 & & 34.66 \\
\hline 朝 & & 鮮 & 済 & & 南 & 6.09 & & 42,66 \\
\hline 朝 & & 鮮 & 支 & & 122 & -0.14 & & -0.33 \\
\hline 小 & 石 & 丸 & 朝 & & 鮮 & 3.10 & & 5.62 \\
\hline 小 & 石 & 丸 & 支 & & 122 & 2.36 & & 10.00 \\
\hline 支 & & 122 & 小 & 石 & 丸 & 15.22 & & 3.60 \\
\hline 支 & & 122 & 朝 & & 鮮 & 14.11 & & 6.05 \\
\hline 朝 & & 鮮 & 小 & 石 & 丸 & 2.47 & & 1.36 \\
\hline & 参考 & & 石丸 & & 0.38 & & & \\
\hline & & 支 & 122 & & 0.09 & & & \\
\hline & & 済 & 南 & & 0.03 & & & \\
\hline & & 朝 & 鮮 & & 0.21 & & & \\
\hline
\end{tabular}


交雑種のそれを比で示せば第 8 表の如くであ る、これによると本実験の結果に招いては， 原種に比べて全体的に高い䞶化性を示してい る、すなわち、＼cjkstart済南種 $\times$ 小石丸種及びマ朝 鮮種×支 122 種の 2 組を除いては，いづれの 交雑種においても，市ととに原種に比して 相当高い趨化性を示していた。

な招この場合，原種に招いては済南種の， いちがくに対する趨化性が 目立つて低かつた のであるが，その交雑種は小石丸種との場合， 小石丸種に比してや〉趨化性が括ちた以外は， いづれの場合も済南種自身に対しては勿論, 相手方の原種に比べてもその值の 低下をみせ ないばかりでなくむしろ相当高かつた。

また特異的なのは早朝鮮種 $\times$ 支 122 種で， 原種は山る程度の趨化性を示したにかっわら ず，交雑種ではむしろ忌避の傾向を示した。 これはまた前述のきくに対する同一交雑種の 淛化性が，両原種の大体中間に位したものと その傾向を非常に異にして扣り，他の交雑種 のきくといちら゙くに対する様相の 相違ととも に，いちら゙くに対する趨化性を支配する遺伝 的因子は，きくに対するとれと異つているこ とを示唆するもので山ろう。

\section{IV. 考按}

A. 純系亘種について

1. 桑葉に対する匍匐速度について

桑葉に対する各系蟻奛の擎匐速度について， 測定した結果は，各蚕種の間にかなりの相違 のあることを認めた．勿論これらの数値は各 蟻盖の桑葉に対する 超化性と云う因子も含ん でいるが，一応これをもつて儀掻の速度とし て表した。

な招著者の使用した亘種はいづれる長年月 の固定を経てきた，形質的には全く異つたも のであるので，この匍匐速度の相違は遺伝的 に支配されているものと惟われる。

2. 自然葉に対する超化性について この場合も蟇種によつてその趨化性が明ら
かに異つていた。たら゙朝鮮種のきくに対する 遛化性が，桑葉に対するるのより高かつたこ とを除いては，一般に試験に使つたそらまめ， やつで，㸚ぎ，いちょ゙く，きくに対する值は 低からた。これは当然期待されたところであ つて，渻者の使用した龺種は野生種ではなく， その唯一の飼料として桑葉に対し長年月に亘 り馴化されてきたつめであろう。

著者の実験材料の配置，すなわち，使用蟻 蚎より被検物質を $4 \mathrm{~cm}$ 距てっ执いたことよ りして，蟻蚕が被検物質に反応するには，当 然嗅覚以外は考兄られない状況に山るので， この超化性が同一查種に掂いても，使用した 自然葉の種類により異つていたことは，藷者 の実験が嗅覚実験であると云うよい裏づけの 一つでも岁り，また小野ら16）17）の実験をる 裹づけるものであろう。

な招朝鮮種のきくに対する趨化性が強かつ たことは，小沢20）の結果と一致していた.

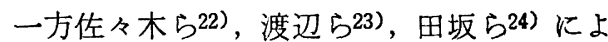
り桑葉中の, 家亘に対し趨化性を有する揮発 性成分の研究は詳細になされているが，きく のそれについての研究は著者には見当らなか つたので，きくの葉のいかなる揮発性成分が このように作用したかは不明であつた。

また佐々木ら22）は家奛（支 110）の各植物 葉に対する感知距離の実験をしているが，こ れわ使用亘も第 3 令で， かつまた実験方法む 異つているので，著者の成績とはかならずし も同一傾向は示さなかつた。

3. 合成試薬に対する趨化性について

小石丸種が供試アルデヒドの大部分に対し 10\%の䟴度で趨化性を示した以外は，他の 3 奛種は供試々薬のすべてに，また小石丸種は エステル，脂肪酸，ヶトン及びアルデヒドの 一部に対し 10\%まで濃度を上げても，赹化性 は示さなからた。また小石丸種が示した趨化 性も決して高いものではなく，その数値は 0.14 から 0.31 の間にあ⿱た。 
国馬 12)，松崎 13) はハッカネズミの運動に 対する各嗅素刺㦸物質の影響について研究を しているが，ハッカネズミの運動が，用いた 試薬の炭素数に関倸して，その運動が增減す ると云う。すなわち，試薬の炭素数が偶数の 場合は， 八ツカネズミの運動が增加する傾向 にあることを報告しているが，著者の場合に は小石丸種に招いても，このような化学的構 造ないしは炭素数こ趨化性との関連は見られ なかつた。

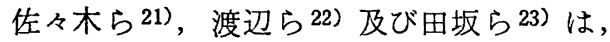
第 3 令の著者と違つた原種を使つているが， 桑葉中の $100^{\circ} \sim 170^{\circ} \mathrm{C}$ 附近で分溜してくる 中性物質殊にその中のアルデヒド及びヶトン 類が趨化性を有するとなしているが，小石丸 種の成績はこれらの 報告と思い合せて興味深 いものがある。

B. 交雑種について

1. 桑葉に対する匍匐速度について

交雑による匍匐速度の原種に 比べての变化 は3つの傾向を示した。

すなわち，原種の両方からの影響が岕らわ れていると惟われる場合と，いづれの原種に 比べてもその速度が，增減のいづれかに片寄 つている場合であつた。

第一の場合は一見 +側の因子が強く作用し て招り，速度の支配するものは伴性遗伝を思 わせた。しかしその他の場合はこうした単純 な遺伝的法則にあてはまらず，简甸速度に関 与する遺伝子の複雑さを思わせた。

2. 自然葉に対する趨化性について

交雑種のきく及びいちら゙くに対する 趎化性 は一般に，原種のそれより高値を示し，また 桑葉に対する䞶化性よりも高いものが，半数 以上を示したことが目立つた。これは単に交 雑種の匍匐速度が，原種のそれに比して高い ものが見られたつめばかりでないことは，例 えば，支 122 種×朝鮮種の交雑は，そのい

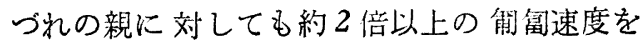
示したにか〉わらず，きくに刘する呰化性は
朝鮮種に比べ，殆んど等しかつた如く，第 5 及び第 6 表を比較してみれば明らかなところ である。こ礼はすなわち，交雑により自然葉 に刘する遛化性も異つてきた結果と考兄て間 違いなからう。

一部の交雑種を除いては，原種の゚゚いつ れの侧に比べても，明らかに赹化性の上犁し たもの，或は低下したものが多く，その方向 は種々であり，また原種との組合せに招いて 充分な解析は加光得なかつたが，いわゆる遺 伝子の再結合によるものと思われ，池田 ${ }^{8)}$ が ハツカネズミの交雑種による味覚実験で示し た例と，招そらく共通の遺伝的機作が働いた ১めによるものであろう。

な招早朝鮮種×支 122 種で，きくに対する 趨化性は大体両原種の中間的な值を示してい たのに，いちら゙くに対するそれは全く逆の傾 向を示した事実は，他の交雑種に括けるきく そいちょ゙くに対する赹化性の相違とつもに， 自然葉にする対超化性を支配する遺伝因子は, 異つていることを示㖫するものであろう.

\section{V. 総 括}

純系蟻虫及びその交雑系を使い，桑葉に対 する匍匐速度，自然葉及び合成試薬に対する 趨化性の実験をしたところ次の結果を得た。

1. 桑薬に対する匍匐速度は, 純系掻に拈 いても，また交雑種に招いても，明らかに系 統間に差があつた。

2. 自然葉に対する遛化性は，純系虫におお いては桑葉に比し一般に低く, 各蛋種間及び 各植物間には差が認めら礼た。

交雑種においては，一部のものを除いては 原種の早令いづれの側に比べても, 上年した もの，或は低下したものが多く，趨化性を支 配する遺伝因子の複雑さを思わせた。

3. 合成試薬に対する 䞡化性は，使用した 1 登種（小石丸種）の多に，アルデこドに対 するものが認められたのみで，そ㣗も余り強 くはなかつた。 
本研究に対し叠児を分与して頂き，かつ御示 咬を賜つた，農林省亘系試験場東北支場の杉山 場長及び鮎沢技官に深謝する。

なお御指導御校閲を睗つた星島啓一郎教授及 び渡辺正男助教授, また統計学的及び遗层学的 解析について種々御示唆を頂いた本学公架衙生 学教室の辻義人教授に深謝する。

\section{文献}

1) Beidler, L.M.: Physiological problems in odor research, Ann. N.Y. Acad. Sci., 58:52, (1954)

2) Wenzel, B.M.: Problems of odor research from the viewpoint of a psychologist, ibid., 58: 58, (1954)

3) Greenspan, J.: Problems of odor research from the viewpoint of the physist, ibid., 58: 62, (1954)

4) Sumner, J.B.: Problems in odor research from the viewpoint of the chemist, ibid., 58: 68, (1954)

5) 長浦小一郎：家虫の味覚について, 医学と生 物学, 47, 15 (1958)

6) 長浦小一郎：家虫の嗅覚について, 医学と生 物学, 48, 96 (1958)

7) 横山定助：ハツカネズミの味覚に関する研究， 福島医微，10，1（1960）

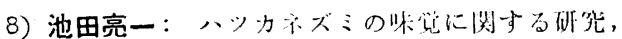
地族衙尘，27，2，(1961）

9）佐藤健象：人間の肌出，味喾改び嗅覚につい て，民族得生，27，1，(1961)

10）池田亮一：人間の嗅喾に関する研究（第1 報）,

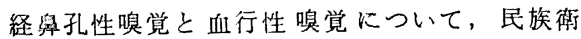
生, 27, 4, (1961)

11）池田亮一：人間の嗅覚に関する研究（籍2報）,
嗅盲について，民族衛生，27，4（1961）

12）国馬正三：ハッカネズミの運動に及ぼす臭素 の影響に関する研究（第1報），民族衛生，24 129 (1958)

13）松崎美佐夫：ハツカネズミの運動に及ぼす臭 素の影響に関する研究 (第 2 報), 民族衛生, 27, 4, (1961)

14）松崎美佐夫, 大井清弥：ヒトの嗅覚に及ぼす クロールプロマジンの影響について，医学と生 物学, 45, 49, (1957)

15）田中義磨：登学，興文社 (1943)

16）小野正男, 岸本時弘, 佐久保正造：㫠児の 嗅覚力について（序報），亘系界報，444，63 (1929)

17）小野正男, 横山健次郎, 佐久保正造：家琶の 嗅覚力之桑染との関係，虫系界報，451，50 (1929)

18）小泉二郎：光線に対する蜮亘の行動, 日本歪 系学雑誌, 19, 417 (1950)

19）宮川千三郎：蟻蛋の行動履歴について，日本 亘采学雑誌, 20,341 (1950)

20) 小沢昇：日本登系学雠誌，19(1950) (21) よ り引用)

21）佐々木周郎，渡辺忠雄，田坂由正：桑葉の揮発 性成分について，(1) 家蚎の趗化性之桑葉の臭 気について，日本登糸学雑誌，20，448（1951）

22）渡辺忠雄，田坂由正：桑葉の揮発性成分につ いて，(2）塩基性，酸性亚びに 2,3 ノカボ二 ル化合物について, 日本虫系学雑誌, 21, 33 (1952)

23）田坂由正，渡辺忠雄：桑葉の揮発性成分につ いて, (3) Paper partition chromatography によるアルデヒド业びにケントの分離につい て, 日本算系学雑誌, 21, 106 (1952) 
some extent against three reagents mentioned above via nostril. The number was 12 out of $500(2.4 \%)$.

The third one was so-called complete smell-blindness. They did not react against reagents both via nostril and blood vessels. The number was 6 out of $500(1.2 \%)$.

Owing to the small numbers of cases, the author could not find any decisive rule of heredity about smell-blindness.

(From the Department of Hygiene,Fukushima Medical College, Fukushima)

A Study on Relationship between the Menstruation Cycle and Olfactory Response

By

Misao MATSUZAKI

The relationship between menstruation cycle and olfactory response against Alinamin was tested in 75 cases according to R; Ikeda's method.

The threshold value was varied in each period, i.c. pre-menstrual, menstrual and post-menstrual periods.

In menstrual period, the threshold value was increased markedly.

(From the Department of Hygiene, Fukushima Medical College, Fukushima)

Genetical Study on the Olfactory Response of Silk-worm

By

\section{Koichiro NAGAURA}

The author made the investigation about the olfactory response of newly hatched silk-worm against leaves of mulberry chrysanthemum, Fatisia japonica, fig, horse bean, and blue onion, and certain number of synthetic chemicals. The results were as follows.

1. The crawing speed against mulberry leave was different among each strains.

2. The olfactory response or chemotropism against leaves of mulberry was more distinct than that against the other leaves in the case of inbred strains, but in the case of certain mixed bred strains, some strains were more sensible against the leaves of latter plants than thet of mulberry.

From above mentioned facts, it might be concluded that the genetic factors have influence on the sensitivity of silk-worm.

3. About chemotropisim against synthetic chemicals, only one strain out of four showed response against certain aldehydes.

(From the Department of Hygiene, Fukushima Medical College, Fukushima) 